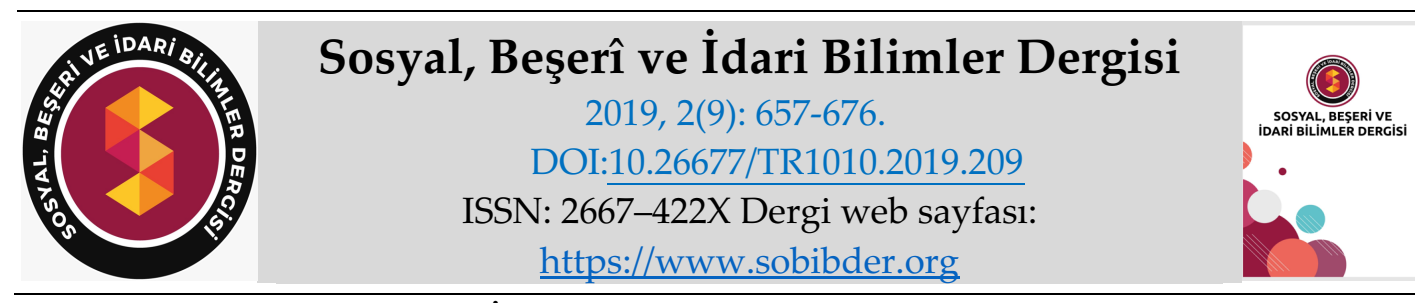

ARASTTIRMA MAKALESI

\title{
Türkiye'de Gençlerin Göç Eğilimini Etkileyen Unsurlar Üzerine Bir Alan Araştırması
}

Ebru KAYA, Doktora Öğrencisi, İstanbul Üniversitesi, Sosyal Bilimler Enstitüsü, Avrupa Birliği Anabilim Dalı, Avrupa Birliği Bölümü, İstanbul, e-posta: ebru.kaya@ogr.iu.edu.tr

ORCID: https://orcid.org/0000-0002-4814-5669

\section{Öz}

Nitelikli beyinlerin göçü, yüksek düzeyde eğitime ve buna bağlı olarak niteliğe sahip işgücünün, daha iyi yaşam ve çalışma olanakları sunan ülkelere gitmesi, son yıllarda uluslararası göç hareketleri içinde payı en fazla artan göç kategorisidir. Kuzey Amerika, Kanada ve Avrupa Birliği (AB) ülkeleri gibi gelişmiş ülkeler, gelişmekte olan ülkelerdeki parlak beyinleri kendilerine çekmek suretiyle, yeni yetenekler ve vasıflı iş gücünü arttırmaktadır. Bu sayede, beşeri sermaye seviyelerini daha da yukarıya çıkararak, gerek ülkesel gerekse, küresel düzeyde stratejik avantajlarını kullanmaktadırlar. Öte yandan, beyin göçünün, göç veren ülkeler açısından yarattığı kaybın çok daha maliyetli olması göz önüne alınmalıdır. Nitelikli beyinlerini kaybeden ülkeler stratejik avantajlarını kaybederler. Bu araştırmanın amacı, Türkiye'de gençlerin göç eğilimini etkileyen unsurları saptamaktır. Bu araştırmanın bulguları, ekonomik faaliyet ve istihdam olanakları gibi unsurların ve bu bağlamda, geleceğe dair kaygıların Türkiye' de gençlerin göç eğilimini etkileyen temel etkenler olduğunu ortaya koymaktadır. Çalışmanın göç veren ülkemiz açısından nitelikli beyinlerin kaybını önlemeye yönelik etkili kamu politikalarının oluşturulmasına yardımcı olacağı düşünülmektedir. Bu araştırmanın bulguları, literatür ve istatistiklere ilaveten nicel yöntem kapsamında anket tekniği ile toplanan verilere dayanmaktadır.

Anahtar Kelimeler: Göç Teorileri, Beyin Göçü, Beşeri Sermaye, Sosyo-ekonomik Değişim.

Makale Gönderme Tarihi: 07.06.2019

Makale Kabul Tarihi: 28.09.2019

\section{Önerilen Atıf:}

Kaya, E. (2019). Türkiye'de Gençlerin Göç Eğilimini Etkileyen Unsurlar Üzerine Bir Alan Araştırması, Sosyal, Beşeri ve İdari Bilimler Dergisi, 2(9): 657-676.

(C) 2019 Sosyal, Beşerî ve İdari Bilimler Dergisi. 


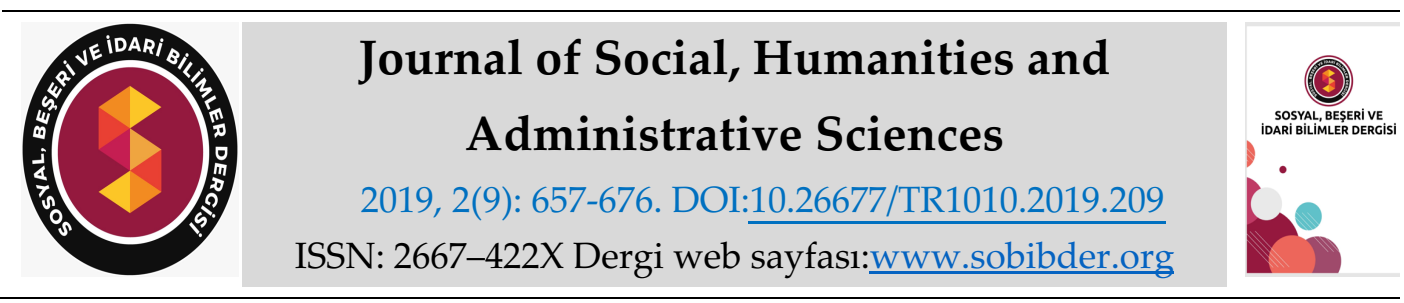

\title{
$\underline{\text { RESEARCH PAPER }}$
}

\section{A Field Research on the Factors that Affecting Youth Emigration Trends in Turkey}

Ebru KAYA, Ph.D. Student, İstanbul University, Institute of Social Sciences, Department of the European Union, İstanbul, e-mail: ebru.kaya@ogr.iu.edu.tr

ORCID: https://orcid.org/0000-0002-4814-5669

\begin{abstract}
The emigration of qualified people and the labor force with high level of education and correspondently quality to the countries that offer better living and working opportunities are the category of emigration that has increased its share in international emigration movements in recent years. Developed countries such as North America, Canada, and the European Union (EU) countries are attracting new talents and qualified labor force by attracting the bright brains of developing countries. Thus, they use their strategic advantages both at national and global level by increasing human capital levels even further. On the other hand, it should be considered that the loss caused by brain drain in terms of emigration countries is much more over costing. Countries that lose their qualified brains lose their strategic advantages. The purpose of this research is to determine the factors that influence young people's emigration trends in Turkey. In this study, factors such as economic activity and employment opportunities, and in this context, concerns for the future support that the main factors affecting the emigration trends of young people in Turkey. It is considered that it will help establish effective public policies to prevent the loss of qualified brains for our sending country. In addition to literature reviews and statistics, the data of this research is based on the data collected by the survey technique within the scope of quantitative method.
\end{abstract}

Keywords: Migration Theories, Bain Drain, Human Capital, Socio-economic Change. Received: 07.06.2019

Accepted: 28.09.2019

\section{Suggested Citation:}

Kaya, E. (2019). A Field Research on the Factors that Affecting Youth Emigration Trends in Turkey, Journal of Social, Humanities and Administrative Sciences, 2(9): 657-676.

(C) 2019 Sosyal, Beşerî ve İdari Bilimler Dergisi. 


\section{Gíriş}

Göç, bir sistem olarak dünya çapında tüm ülkeleri kapsayacak bir duruma gelmiştir. Göç kısa veya uzun vadeli olabilir. Göçmenler bir ülkede yaşayabilir ve başka bir ülkede çalışabilirler. Göç veren ve göç alan ülkeler arasında hareket edebilir (Geddes ve Scholten, 2016: 6). Yaşam kalitesinin yüksekliği ve hümanist düşüncelerin hâkim olduğu bir coğrafyada yaşama fikrinin, insana değer vermeyen ve baskıcı bir yapıdan gelen insanlar için çok büyük değere sahip olduğunu söylemek mümkündür.

Castles, de Haas ve Miller'e (2014: 123) göre büyük ölçekli göçlerin motivasyonları esas olarak ekonomiktir. İnsanların bir ülkeden diğerine hareketi temel olarak gelir ve gelir eşitsizliğinden kaynaklanır. Bu unsurlar, ekonomik göçün güçlü itici güçleri olarak düşünülebilir. Öte yandan, uluslararası göç dolaşımının, göçmenlerin ekonomik nedenlerle fakir ülkelerden zengin ülkelere geçerken sadece basit itme baskılarına maruz kaldıkları anlamına gelmemektedir. Gelir ve refah eşitsizliğine ek olarak, nüfus yapısının genç yetişkinlerle birlikte hareket etme kabiliyeti üzerindeki etkileri, genellikle yaşlılardan daha fazla hareket etme kabiliyeti, potansiyel göçmenleri daha önce göç etmiş olan ve yeni bilgi ve iletişim teknolojileriyle kolaylaşabilen aile, eş, dost ve akrabalara bağlayan göçmen ağlarının çalışması ve etkileri, evrensel değişimin insanların geçim kaynakları üzerindeki etkileri, çatışma dahil siyasi değişimlerin etkileri gibi diğer faktörleri de sıralamak mümkündür (Geddes ve Scholten, 2016: 6).

Bu artan göçe, Soğuk Savaş'ın bitmesi ve Sovyet Bloğu'nun çöküşü, küresel yeniden yapılanmaya yeni boyutlar, ekonomik büyüme ve sürekli işgücü talebi, AB'nin genişlemesi, "neoliberal" ekonomik politikaların yanı sıra üretimin uluslararasılaşması, dağıtım ve yatırım etmenleri de eklenmiştir (Castles, de Haas ve Miller, 2014: 123-125). Salomoni'ye göre, son yirmi yılda uluslararası göç sisteminde görülen en çarpıcı özelliklerden biri, göç veren ülkelerin de değişerek, göç alan ülkelere dönüşmesi ve Avrupa'daki göç hareketlerinin ana çekim merkezi haline gelmiş olmasıdır (2016: 417). Genç göçmenlerin hedefinde öncelikle AB ülkeleri, Kuzey Amerika ve Okyanusya bulunmaktadır.

Günümüzde, en yaygın göç kategorisi haline gelen genç ve teknik olarak yetenekli kişilerin göçü, beyin göçü olarak da bilinen olgudur. İlk olarak İngiltere' de ortaya atılan kavram olarak "beyin ihracatı", kısa zamanda kıtanın tamamında kullanılmaya başlanan bir deyime dönüşmüştür (Sampson, 1969: 212). Basit bir deyişle, beyin göçü, genç ve teknik olarak yüksek vasıflı kişilerin bir ülkeden diğer ülkeye toplu olarak göç etmesi olarak nitelendirilebilir. İnsan kaynaklarının yeterliliği, bilgi temelli ekonominin gelişmesinde ana etkendir (Oğuz, 2011: 714). Beyin göçünün gelişmiş ülkeler açısından önemli yararları vardır. Beyin göçü yüksek becerili/vasıflı işgücünde varolan eksikliklerin giderilmesinde, Ar-Ge faaliyetleri ve ekonominin motoru olarak nitelenen sektörlerde üretimin verimliliğine katkı sağlar. Teknoloji ihracatı için fırsat yaratır. Ayrıca gelişmiş ülkeler ücretli yüksek öğretim programları yolu ile önemli bir gelir kaynağına erişir ve üniversitelerinden mezun olan yabancılar arasından en iyilerini seçme imkânını bulabilirler.

Buna karışılık, beyin göçü gelişmekte olan ülkeler açısından önemli kayıplara yol açan endişe verici bir sorundur (Toksöz, 2006: 231). Bu endişelerin sebebi, beyin göçünün göç veren ülkeler açısından ortaya çıkardığ kaynak harcanmaktadır. İş karakteristikleri ve gelirler açısından işgücü piyasası seçenekleri olarak geri kazanılır (Anderson, 2015: 16). Belli bir süre yurt dışında kalıp, orada bilgi ve deneyimini arttırdıktan 
sonra, nitelikli işgücünün ülkesine dönmesi ile ortaya çıkan kalkınma etkileri çok değerlidir. Bununla bağlantılı olarak, yaşanan deneyimler, beyin göçü düzleminde geriye dönüşlerin, kalkınma çabalarına katkı sağlamasının ancak bu konuda bilinçli kamu politikalarının oluşturulması ve uygulanmasına bağlıdır. Uluslararası göçün zaman zaman beyin göçü yoluyla gelişmekte olan kaynak ülkelerin zaten sınırlı becerilerini tükettiğini vurgulamak önemlidir (Sert, 2014: 521). Nitelikli beyinleri kaybeden devletler, stratejik avantajlarını kaybedeler. Bütün hükûmetler bu kayıp nedeniyle endişe duymakta ve engellemek için yollar aramaktadırlar (Sampson, 1969: 213).

İçinde insani ve sosyal sermayenin ${ }^{1}$ bulunduğu akışlar sayesinde, ulus devletlerin ve toplumlarının hangi yollar ile dönüştüğü ve uluslararası göçün bu dönüşüm içerisindeki konumu, ancak yaşanılan topraklardaki toplumsal dönüşümler ışığında ele alınarak ve göçmenler bu dönüşümleri oluşturan değişikliklerle beraber hareket eden kişiler olarak ele alınmasıyla anlaşılabilir (Özkul, 2016: 499).

Bütün bu etmenler, tartışılan teorilerin önemini göstermektedir. Göçü belirleyen etmenlere ilişkin alanında yapılmakta olan araştırmalarda, çesitli kavram ve varsayımlar, analiz düzeylerini kullanan farklı teorik model veya perspektifler bulunmaktadır (Arango, 2000).

Bu çalışmanın ilk ayrımında göç olgusu üzerine üretilmiş olan teorilerin arkasında yatan temel varsayımlar, kısıtları ve uygulama koşulları genel hatlarıyla aktarılacaktır. İkinci ayrımında, gençlerin göç eğilimini etkileyen unsurlar ve Türk gençlerinin göç etmeye ilişkin algıları ve beklentileri araştırılacaktır. Çalışmanın son ayrımında, beyin göçünü önlemeye yönelik politika önerileri sunulacaktır.

\section{GÜNCEL GÖÇ TEORILERINNE GENEL BAKIŞ}

Alt bölümde, göç eğilimlerinin tetikleyici etmenlerine ilişkin güncel teorilerin temel önermeleri, birbirleriyle ilişkili oldukları hususlar ve farklılıklar kısaca açıklanmaktadır.

\section{Göç Akışını Etkileyen Çekme ve İtme Koşulları}

Göç olgusu üzerine yazılmış olan oldukça kapsamlı bir yazın bulunmasına rağmen, bu bölümde temel göç teorileri üzerinde durulmaktadır. Öncelikle, insanların neden göç ettiği konusu ile ilgilenen göç yazınında en fazla vurgu yapılan Lee'nin (1966) itici-çekici faktör terminolojisidir.

Lee, göçü, kısaca, insanların köken/kaynak ülkelerinden varış yerlerine taşınma hareketi olarak nitelendirmektedir (Lee, 1966). Lee'nin vurguladığı gibi, “Ne kadar kısa, ne kadar kolay, ne kadar zor olursa olsun, her göç eylemi bir kökeni, bir varış noktasını ve müdahale eden engelleri içerir" (Lee, 1966, : 49). Bu engeller, göç eylemindeki faktörler olarak kabul edilir. Lee'ye göre, göç için karar verme süreci, sebeplerin tipolojisine dayanabilir. İlk olarak, yaş, cinsiyet, mesleki eğitim, aile ile ilgili

\footnotetext{
${ }^{1}$ Beyin göçü kavramında sermaye kelimesi bilgi ve beceri olarak düşünülebilir. Sermayenin beceri ve bilgiyi temsil etmesinin temel nedenlerinden biri, insanların "eğitim aldıkları ve eğitildikleri ülkeden göç ettikleri, sermayenin de oradan ayrıldığı, yani o ülke tarafından kaybedildiği ve hedef ülke tarafından kazanıldığı zamandır. Köken/kaynak ülke açısından bakıldığında, göçmenlerin eğitim ve öğretimine yaptığı ilk yatırımın faydasız olmasıdır" (Wächter, 2006: 53).
} 
koşullar, barınma koşulları ve diğerleri gibi nesnel kişisel özelliklere dayalı olabilir (Lee, 1961, : 5052). İkincisi, öznel faktörlerdir. Bu faktörler örneğin, güdüler, bilgiler, durumun değerlendirilmesi vb. olarak siralanabilir.

Lee'nin ana argümanı, uzaklık/mesafe, fiziksel ve politik engeller ve bağımlıların olması gibi değişkenlerin göçü engelleyebileceğidir. Göçün seçici bir süreç olduğunu savunur. Çünkü, yaş, cinsiyet ve sosyal sınıf gibi farklılıklar kişilerin itme-çekme faktörlerine nasıl tepki verdiğini etkilemektedir. Bu koşullarda araya toplanan engellerin üstesinden gelme yeteneklerini şekillendirir (Lee, 1966). Lee, etkili faktörleri dört ana grupta özetlemektedir. Bu faktörlerin ilki, kaynak yerle ile ilgili unsurlar, ikincisi, hedef yer ile ilgili unsurlardır. Lee, bunların birbirleri ile bağlantılı olduğunu iddia etmektedir. Üçüncü faktör grubu ise, engellerin üstesinden gelme kabiliyetine sahip olanlar ve sonuncusu kişisel faktörlerdir (Lee, 1966).

Özetleyecek olursak, yukarıdaki bu bölümde, araştırma sorusunu analiz etmek için göç etme kararında etkili olabilecek faktörlere ilişkin genel bir görünüm verilmiştir. Göç etme kararları toplumun ekonomik, sosyal, politik, kültürel, demografik koşullarına dayanmaktadır. Bu nedenle, bu literatür taraması, insanları zorlayan ya da göçe çeken, göçü etkileyen faktörler arasında genel bir ayrım olduğunu göstermektedir. Tüm bu itme ve çekme faktörlerinin özet tablosu Tablo 1'de sunulmaktadır.

Kurekova'ya göre, emek piyasasının aktif ve pasif olması, eğitim, aile desteği, sağlık durumunun iyi olması gibi belirleyici etmenler bireylerin yaşamlarını önemli ölçüde etkilemektedir. Bunların erişilebilirliği ve cömertliği hem direkt formatta hem de geçişin etkilerinin aracıllğını üstlenen vasitalar olarak göç eğiliminin belirleyici kurumsal etmenleri olarak kabul edilebilir (Kurekova, 2011).

Göç konusuna ilişkin araştırma alanı oldukça karmaşıktır ve çok sayıda analiz seviyesi sunmaktadır. Bu alanda, itici-çekici faktörler dişında dört farklı soru araştırılmaktadır: göçün kökenleri; göç akımlarının yönü ve sürekliliği, göçmen işgücünün kullanılması ve göçmenlerin sosyo-kültürel adaptasyonları (Portes, 1999). Bu alanların her biri farklı seviyelerde ve farklı araçlarla analiz edilmekte ve bireysel dikkat gerektirmektedir. Bu alanların birini veya ikisini hedef alan 'orta-aralık' teorilerin tümünü içeren beyandan ziyade, göçün bu dört yönünün tamamını açılayabilen bir teori geliştirilmesi göç kuramlamasında oluşturulmasında arzu edilen hedef olmaya devam etmektedir (Massey, 1999; Arango, 2000).

Göç eğilimlerini etkileyen unsurları açıklayan baskın teori, temel varsayım olarak, göçün, çoğu ekonomik olmakla beraber, ek olarak psikolojik yönü de bulunan, göreceli fayda ve maliyete ilişkin ussal ekonomik düşüncelerle stimüle edildiğini öne sürmekte olan neoklasik teoridir (Todaro ve Smith, 2006: 342). 
Tablo 1: Ekonomik, demografik, sosyo-kültürel, politik ve çeşitli koşullara dayalı itici ve çekici faktörler

\begin{tabular}{|c|c|c|}
\hline Koşullar: & İten Faktörler & Çeken Faktörler \\
\hline $\begin{array}{c}\text { Ekonomik } \\
\text { Faktörler }\end{array}$ & $\begin{array}{l}\text { - Yeterli iş olmaması } \\
\text { - Ekonomik kriz } \\
\text { - Kısıtlı fırsatlar } \\
\text { - Zorla çalıştırma } \\
\text { - Zayıf konut } \\
\text { - Verimsiz/yetersiz tıbbi } \\
\text { bakım } \\
\text { - Mal varlığı kaybı }\end{array}$ & $\begin{array}{l}\text { - Daha iyi kariyer olanakları } \\
\text { - Daha iyi yaşam koşulları } \\
\text { - Sanayi } \\
\text { - Finans desteği: eğitimin finanse edilmesi: } \\
\text { burslar, devlet tarafından finanse edilen } \\
\text { araştırma programları } \\
\text { - Daha iyi tıbbi bakım } \\
\text { - Gelişmiş ülkelerin üniversitelerinin veya } \\
\text { araştırma enstitülerinin çekiciliği }\end{array}$ \\
\hline $\begin{array}{l}\text { Demografik, } \\
\text { Sosyo- } \\
\text { kültürel } \\
\text { Faktörler }\end{array}$ & $\begin{array}{l}\text { - Evlenme firsatının zayıf } \\
\text { olması } \\
\text { - İlkel koşullar } \\
\text { - Dini ırkçılık } \\
\text { - Zorbalık }\end{array}$ & $\begin{array}{l}\text { - Evlenme fırsatının daha iyi olması } \\
\text { - Hoşlanma/keyif alma } \\
\text { - Yurt dışında yaşam deneyimi } \\
\text { - Farklı kültürleri tanıma } \\
\text { - Yüksek eğitim seviyesi } \\
\text { - Akrabalar } \\
\text { - Arkadaş bağlantıları } \\
\text { - Sosyal ağ }\end{array}$ \\
\hline $\begin{array}{l}\text { Politik } \\
\text { Faktörler }\end{array}$ & $\begin{array}{l}\text { - Politik korku veya zulüm } \\
\text { - Politik kriz } \\
\text { - Siyasi dengesizlik } \\
\text { - Ölüm tehditleri } \\
\text { - Savaş } \\
\text { - Askeri darbeler } \\
\text { - Yolsuzluk }\end{array}$ & $\begin{array}{l}\text { - Siyasi veya dini özgürlük } \\
\text { - Diğerlerine karşı daha fazla toleransı olan } \\
\text { toplumlarda yaşama arzusu } \\
\text { - Güvenlik }\end{array}$ \\
\hline $\begin{array}{l}\text { Diğer } \\
\text { Faktörler }\end{array}$ & $\begin{array}{l}\text { - Ayrımcılık } \\
\text { - Yabancı istilası } \\
\text { - Sosyal istikrarsızlık } \\
\text { - Kitlık veya kuraklık } \\
\text { - Doğal afetler } \\
\text { - Kirlilik }\end{array}$ & $\begin{array}{l}\text { - Cazip iklim koşulları } \\
\text { - Macera/deneyim }\end{array}$ \\
\hline
\end{tabular}

Kaynak: Martiskova, 2013: 18'den uyarlanmıştır.

\section{Neoklasik Göç Teorisi: Makro ve Mikro Yapı}

Neoklasik göç teorisi, göçlerin itici gücünü piyasadaki işgücüne dönüş farklılıkları olarak ortaya koymaktadır. (Hicks, 1932; Lewis, 1954; Harris ve Todaro 1970) Bu yaklaşıma sahip teorisyenler, çalışmalarında göçleri, ekonomik gelişim sürecinde açılamak için ilk olarak geliştirilen temel modele göre, göç olgusunun ülkelerdeki veya piyasadaki işgücü pazarı darlığının heterojen derecelerinden doğan, gerçek ücret farklılıklarının bir sonucu olduğunu vurgularlar. Yine bu teori, 
işgücü arz ve talebindeki coğrafi farklılıklar ve bunun neticesi olarak işgücü zengini ülkelere karşılık sermaye zengini ülkeler arasındaki farklılıkların göçün itici gücünü oluşturduğunu önermektedir. Diğer bir ifade ile neoklasik yaklaşımın en önemli argümanının ücretler üzerinde yoğunlaştığını söylemek mümkündür.

Öte yandan, göç edebilme imkani maliyetlerle ilişkili olabildiğinden, fazlaca göç veren ülkelerin en yoksul ülkeler olmadığı gibi göçenlerin de en yoksul kişiler olmadığı sonucuna varılabilir (Massey vd., 1998; Faist, 2000; Dustmann vd., 2003; de Haas 2008).

Neoklasik makro düzey çalışma, mikro düzey kişisel tercih modeline aktarılarak, göçün insan sermayesi teorisi olarak adlandırılmıştır (Todaro, 1969). Sjaadstad (1962) tarafından sunulmuş olan insan sermayesi teorisi, kişinin sosyo-demografik özelliklerini mikro-düzeyde göçün önemli belirleyici etmeni olarak birleştirerek neoklasik çerçeveye zenginlik katmaktadır (Bauer ve Zimmermann, 1999). Bu analizlerin temel ekseninde sağlayacağı kazançları en fazla düzeye çıkartma hedefi ile göç edebilen ussal bir birey yer alır. İnsan sermayesi olarak eğitim, beceri, medeni durum, yaş, cinsiyet, meslek, emek piyasasındaki güncel durum, bireysel tercihler ve beklentiler kimin göç edeceğini ve etmeyeceğini etkileyen önemli etmenlerdir. Bireyler arasındaki heterojenlik önemli bir faktördür. Aynı göç veren ülkedeki farklı bireyler, göç etmek için farklı eğilimler gösterebilirler. Ayrıca, farklı göç alan ülkeleri seçebilirler (Bonin vd., 2008). Göç etme ihtimalinin eğitim düzeyi yükseldikçe arttığ1 ve ilerleyen yaşlarla birlikte azaldığı gösterilmiştir (Bauer ve Zimmermann, 1999). İnsan sermayesi teorisine göre, göçenler göreceli olarak daha becerili olma eğilimindedirler.

\section{A ̆ Kavramları Çerçevesinde Göçün Devamlılı̆̆1}

Şebeke/ağ ve göç sistemleri teorileri, özellikle düşük vasıflı göçmenleri engellemek için hükûmetin girişimlerine rağmen göçün neden devam ettiğini veya hatta artmakta olduğunu anlamamıza yardımcı olur (Castles, de Haas ve Miller, 2014: 123-125). Şebeke/ağ teorisi, göçü başlatan belirleyici faktörlerden ziyade göçü zaman ve mekânda neyin sürdürdügüne odaklanır (Massey vd., 1993). Genellikle kurumsal yapılar halinde evrimleşen göçmen şebekeleri\# ücret farklılıkları veya işe alım politikaları devamlılığını sürdürmediği halde göçün neden devam ettiğinin açıklanmasına yardımcı olur. Diaspora veya ağların varlığının, gidecekleri destinasyonları tercih etmeye çalışan göçmenlerin kararlarını etkileme olasılığı bulunmaktadır (Vertovec 2002; Dustmann ve Glitz, 2005). Şebeke/ağ teorisi ayrıca göç modellerinin ülkeler arasında neden eşit şekilde dağılmadığını ve daha ziyade bunların göç rejimleri adı verilen yapıları oluşturma eğilimlerinin nasıl oluştuğunun da açıklanmasına yardım eder (Faist, 2000).

Şebeke/ağ teorisi, öncülüğünü Magobunje'nin (1970) yaptığı göç sistemleri teorisi adiyla bilinmekte olan bir başka yaklaşımla bağlantılıdır. Bu teorinin ana varsayımı ise, gerek göç veren gerekse göç alan tarafların her ikisinde de sosyal, kültürel, ekonomik ve kurumsal koşulları değiştirdiği ve göç süreçlerinin içinde faaliyet gösterdiği bir gelişme alanının tamamını oluşturduğu yönündedir (de Haas, 2009b). Bu teori göç hareketlerinin daha önce göç veren ve göç alan devletler arasında, koloni (tarihsel) bağlar, ticaret, yatırım akışları vb. gibi bağlantılardan kaynaklandığını ileri sürmektedir (Castles ve Miller, 2009).

Ortaya konan yaklaşımlar göç sürecinin daha bütünsel olarak anlaşılmasını hedeflemektedirler. Bu yaklaşımlar, bireysel veya topluluk halinde kişilerin eylemi ve daha geniş kapsamlı değişim süreçleri 
arasındaki bağlantıları yeniden teorize etme arayışındadırlar. Dünyanın farklı köşelerindeki bireylerin bulabildiği fırsatları ve üstlendiği riskleri etkileyebilen, değişen dünyaya ve piyasaların örgütlenmesi ve siyasetin değişen kurallarına işaret etmektedirler.

\section{TÜRK GENÇLERINN GÖÇ ETMEYE İLIŞKINN ALGILARI ve BEKLENTILERİ}

İnsanların neden göç ettiği konusu ile ilgilenen araştırmaların fazlaca bölümü yukarıda teorik çerçevede açılandığı üzere uluslararası göçü tetikleyen itici - çekici faktörlere vurgu yapmaktadır (Sert, 2014 :511). Türkiye' de farklı dönemlerde beyin göçüne ilişkin yapılan araştırmalarda ortaya çıkan ortak sonuçlardan biri, yüksek vasıflı bireylerin göç etmelerinde öncelikli faktörlerin mesleki alanda duyulan endişeler olması ve bu unsuru ekonomik unsurlardan kaynaklanan sorunların takip etmesidir (Toksöz, 2006: 231). Örneğin; Türkiye, Fas, Mısır, Senegal ve Gana'dan göç eden bireyleri inceleyen Avrupa Komisyonu ve Eurostat işbirliği ile bir grup araştırmacının araştırma sonuçlarında, kişisel beklentiler ve kaynak ülkedeki ekonomik büyüme imkanlarındaki eksilikliklerin göç etme niyetini tetikleyen başlıca itici güç olduğu saptanmıştır.

Göç etme eğiliminde olan Türk gençlerin hedefinde ise AB ülkeleri bulunmaktadır (2010: 84). Türkiye Araştırmalar Merkezi'nin (-23.05.2016 tarihinde-) ortaya koyduğu bir raporda, durgunluk sebebiyle "AB ülkelerinin Türkiye kökenli göçmenler için bir çalışma cenneti olmaktan çıktığını, fakat buna rağmen, ülkemizde yaşanmakta olan yüksek işsizlik nedeniyle, $A B^{\prime}$ ye yönelen göç eğilimini durdurmaya yetmediğini göstermektedir" (Özcüre, 2016: 239).

Avrupa ve dünya ekonomik senaryosu, genç göçmenler için koşulları aşağı yukarı çeken, az ya da çekici olarak tanımlayabilecek diğer ayırt edici özellikleri sunmaktadır. Yeni işçi ve profesyonel kuşakları, ülkeler arasında nispeten daha elverişli veya daha az kritik sosyo-ekonomik durumlarda olan rekabetin yoğun olduğu bir ortamda hareket etmektedir (Stalker, 2000).

İşçilerin daha gelişmiş batı ülkelerine olan uluslararası akışı, ekonomik küreselleşmenin büyümesiyle yoğunlaşmıştır (Castells, 2000; Arango, 2000). Bu bağlamda, Avrupa işgücü piyasası, hareketliliği ve insan sermayesinin gelişmesini teşvik etmek ve kolaylaştırmak için AB üyesi ülkeler arasındaki topluluk direktifleri ve stratejik anlaşmalar etrafında yapılandırılmıştır. AB üye ülkeleri, yetenek arayışlarını küresel bir düzeye çıkarmaya hazırlardır. Küreselleşme araçları insan kaynakları stratejilerini değiştirmiştir. Artık, ulusal düzeyde hükümetler tarafından yüksek vasıflı emeği çekme ve değiş tokuş etme eğilimi bulunmaktadır. Çünkü, düşük beceri seviyesine sahip kişilerce kitlesel göç için çok az ihtiyaç duyulacaktır (Oğuz, 2011: 714). İnsan sermayesi perspektifinden bakıldığında, kaynaklar daha kabiliyetli olmalıdır ve pasif yeniden dağıtım hedeflerine hitap etmelidir (Anderson, 2015: 18).

Sampson'a (1969: 212) göre ise, "ilim adamlarını çeken yalnızca kazanç değil, imkân ve ilme saygısının dayanılmaz çağrısıdır". Son olarak, normatif ve ekonomik boyutlarla birlikte ve bu çalışmada da vurgulandığı gibi, uluslararası ulaştırma ağlarının büyümesi ve yoğunlaştırılması, maliyetler, frekanslar ve genişleme açısından daha yüksek erişilebilirlik, göçü kolaylaştıran diğer unsurlardır. Kaynak/köken ülke ile göçmenlerinin gideceği ülke arasındaki iletişimin sürdürülmesi, bu bağlamda, yüksek hızlı demiryolu bağlantılarının ya da hepsinden önemlisi, düşük maliyetli 
havayollarının geniş yayınımı ile üretilen uluslararası hareketlilik olanakları düşünülmesi gereken önemli etkenlerdir (Tassinopoulos ve Werner, 1998).

Tüm bu etkenler, genç göçmenler için çekici ve erişilebilir olan hareketlilik ve iş için çeşitli fırsatlar yaratmaktadır. Bu anlamda, az ya da çok uzun süren göç projelerini göz önünde bulundurarak, gerek göç eylemini gerçekleştirirken gerekse, yolculuklarının hedeflerini seçerken kişisel ve iş beklentilerinin formülasyonunu etkileyen unsurlardan bahsedilmektedir. Aynı şekilde, gençlerin coğrafi hareketliliğini destekleyen motivasyon ve gerekçeleri daha iyi anlamak için, ekonomik krizin son yıllarında Türk işgücü piyasasındaki durumlarını dikkate almak gerekir (Injuve, 2012 :123). Türkiye açısından, yakınsama gelecekteki emek akışları için önemli çıkarımlar olabilir. Teorik olarak uzun veya orta vadede büyüme potansiyeli nedeniyle göç basıncı tipik olarak azalacaktır. Bununla birlikte, genç Türkler hâlâ Batı' da daha iyi kariyer fırsatları aradıkları için yaşam tarzı faktörlerinden dolayı Avrupalı şirketler genç Türkleri cezbetmeye devam edecektir (Oğuz, 2011: 709).

\section{ARAŞTIRMANIN AMACI}

Bu araştırmanın amacı, Türkiye'de gençlerin göç eğilimini etkileyen unsurları saptamaktır. Bu araştırmanın, Türkiye'de gençlerin göç eğilimini etkileyen unsurları saptayarak, göç veren ülkemiz açısından nitelikli beyinlerin kaybını önlemeye yönelik etkili kamu politikalarının oluşturulmasına yardımcı olacağı düşünülmektedir.

\section{YÖNTEM}

Araştırmada temel olarak ilgili literatür ve istatistiklerden yararlanılmaktadır. Bunlara ilaveten bu araştırmanın verileri, 2019 yılı Mart - Nisan döneminde nicel yöntem kapsamında anket tekniği ile yapılan online anket çalışmasına dayanmaktadır. ${ }^{2}$ Tesadüfî örnekleme yöntemine göre 122 kişiye ulaşılarak anket yapılmıştır. Katılımcıların, ankette yer alan toplam 36 soruya verdikleri cevaplara faktör analizi tekniği uygulanmıştır.

Araştırmada veri ve bilgilerin toplanması için geliştirilen bu anketin içeriği üç temel bölümden oluşmaktadır: Birinci bölümde katılımcıların genel özelliklerini yansıtacak 8 soru yönetilmiştir. İkinci bölümde göç ile ilgili 14 soru yönetilmiştir. Üçüncü bölümde ise, istihdam/ekonomik durum ve geleceğe ilişkin beklentilere ilişkin değerlendirmeleri içeren toplam 8 soru yönetilmiştir. Sorular beşli Likert ölçülerini oluşturan değerler; 1- Hiç Katılmıyorum 2- Katılmıyorum 3- Kararsızım 4Katılıyorum 5- Tamamen Katılıyorum, şeklinde cevap verilmesi planlanmıştır. Veri toplama aracı olarak kullanılan anket tekniğinin güvenilir ve geçerli bir teknik olduğu varsayılmıştır. Katılımcıların anket sorularına verdikleri cevapların geçerli ve güvenilir oldukları varsayılmıştır.

2 Anketlerle ilgili genel veriler için bkz. Ek 1. 


\section{Araştırmanın Evreni, Örneklemi ve Sınırlılıkları}

Bu araştırmada, Türkiye' deki mevcut duruma dayanarak, gençlerin göç eğilimini etkileyen unsurlar 122 genç birey üzerinden incelenmektedir. Anket çalışması, 18-30 yaş arasında olan genç bireyler ile yapılmıştır. Katılımcıların yaş dağılımı; $(\% 20,2)$ oranında 18-20 yaş arası, $(\%$ 63,6) 21-25 yaş arası, $(\% 16,2)$ ise 26-30 yaş arasındadır. Katılımcıları, $(\% 57,2)$ kadın $(\% 42,8)$ erkek oluşturmaktadır. Akademik seviyeler; $(\% 39,3)$ ögrenci, $(\% 37,6)$ üniversite mezunu, $(\% 17,3)$ yüksek lisans ve dengi okul mezunu, $(\% 4)$ lise, $(\% 1,2)$ meslek lisesi mezunudur. Katılımcıların medeni hali, $(\% 74,6)$ oranında bekar, $(\% 23,1)$ oranında evlidir.

\section{Verilerin Analizi}

Anketler, katılımcıların çalışmada odak kriterlerini doğruladıktan sonra ayrıntılı bir veri temizliğine tabi tutulmuştur. Aynı şekilde, anketi asimile etmek için çok düşük olduğu düşünülen sürede yanıtlananlar ve bu çalışmada odaklanan yaş grubu dışında kalan katılımcıların yanıtları da elenmiştir. Elde edilen veriler, SPSS programında değerlendirilmiştir. Verilerin analizinde; oran ve yüzde dağılımı ve istatistiksel tekniklerden; Faktör analizi, Kaiser-Meyer-Olkin (KMO) testi ve Bartlett testi kullanılmıştır. Analizler yapılarak şu bulgulara ulaşılmıştır.

\section{BULGULAR ve YORUM}

Anket yöntemi ile elde edilen bulgular faktör analizi yapılarak açıklanmaya çalışılmıştır. Öncelikle, yapılan örnek büyüklüğünün yeterli düzeyde olduğunu belirleyen Kaiser Meyer Olkin testi kullanılmıştır. Kaiser-Meyer-Olkin testin 0,5 den büyük çıkması gerekmektedir. Kaiser-Meyer-Olkin (KMO) ölçütüne göre KMO değeri 0.86 değeriyle örneklem büyüklüğü faktör analizi için yeterli düzeydedir. Bartlett'in testi de sıfır çıkmalıdır ve analizde sıfır çıkmıştır. Sonuç anlamlıdır.

Faktör çıarım yöntemi olarak Temel Bileşenler Yöntemi (Principal Component Analysis), faktör döndürme yöntemi olarak da varimax seçilmiştir.

Faktör analizi için 10 sorudan oluşan 10x10 lik bir korelasyon matrisi oluşturulmuş ve faktör analizin uygulamasına geçilmiştir. Türkiye'de gençlerin göç eğilimini etkileyen unsurlar belirlenmeye çalışılmıştır. Türkiye' de gençlerin göç eğilimini etkilediği düşünülen faktörlerin, iki ana gruba göre dağılımı gözlemlenmiştir.

Birinci faktör toplam içinde 4,622 Öz değer ile \%48,622 varyansa sahip olduğu, ikinci faktör 2,528 Öz değer ile \%25,283 varyansa sahip olduğu belirlenmiştir. İki faktör toplam değişkenliğin \% 73.9'unu açıklamaktadır.

Birinci faktör, yedi değişkeni kapsamaktadır. Bunlar; yaşamakta oldukları ülkede (Türkiye'de) istihdam beklentileri, gelir/maaş beklentileri, eğitim beklentileri, mesleki deneyim beklentileri, hedeflere ulaşmak için geçmesi gereken zamanla ilgili beklentiler, kişisel deneyimler ile edinilen beklentiler, toplumun kişiden beklentileri gibi hususların hangilerinin ne derece karşılandığının 
değerlendirilmesine ilişkindir. Bu faktöre “Ekonomik beklentilerin karşılanması etkeni" başlığ1 verilebilir.

İkinci faktör, üç değişkeni kapsamaktadır. Yeni deneyimler için fırsat, farklı kültürleri tanıma fırsatı, yeni insanlarla tanışma/yeni bir sosyal ağ kurma fırsatı gibi etmenlerin göç etme isteklerini derecelendirilmesine ilişkin alt başlıklarından oluşmaktadır. Bu faktöre "göç etkeni" başlı̆̆1 verilebilir.

Faktörlerde yer alan değişkenleri yeterince açıklamak için Varimax dik döndürme yöntemi uygulanarak bu faktörlerin değişkenlere göre dağılımı Tablo 2' de verilmiştir.

Tablo 2 Döndürülmüş Bileşenler Matrisi

\begin{tabular}{|c|c|c|}
\hline \multicolumn{3}{|c|}{ Döndürülmüş Bileşenler Matrisi ${ }^{a}$} \\
\hline & \multicolumn{2}{|r|}{ Bileşenler } \\
\hline & 1 & 2 \\
\hline Mesleki deneyim beklentileri & ,913 & \\
\hline $\begin{array}{l}\text { Hedeflere ulaşmak için geçmesi gereken } \\
\text { zamanla ilgili beklentiler }\end{array}$ & , 896 & \\
\hline Ĕgitim beklentileri & ,858 & \\
\hline Gelir/maaş beklentileri & ,841 & \\
\hline İstihdam beklentileri & ,790 & \\
\hline Kişisel deneyimlerimle edindiğim beklentiler & ,779 & \\
\hline Toplumun benden beklentileri & ,730 & \\
\hline Yeni deneyimler için fırsat & & ,934 \\
\hline Farklı kültürleri tanıma fırsatı & & ,908 \\
\hline $\begin{array}{l}\text { Yeni insanlarla tanışıma/yeni bir sosyal ağ } \\
\text { kurma fırsatı }\end{array}$ & & ,904 \\
\hline \multicolumn{3}{|c|}{$\begin{array}{c}\text { Metod: Temel Bileşenler Yöntemi } \\
\text { Rotasyon Metodu: Kaiser Normalizasyonu'na Dayalı Varimax. }\end{array}$} \\
\hline \multicolumn{3}{|c|}{ a. Rotasyon 3 tekrarlamada bir araya gelmiştir. } \\
\hline
\end{tabular}

Ekonomik beklenti faktöründe en düşük yük alan değişkenin değeri 0.73, en yüksek yük alan değişkenin değeri ise 0.91 'dir. Cronbach's Alpha katsayısı 0.92 olan faktörün güvenilirlik düzeyi yüksektir.

Göç-Ekten faktöründe ise en düşük yük 0.90, en yüksek yük ise 0.93'tür. Faktörün Cronbach Alpha güvenilirlik katsayısı ise 0.90 'dır ve yüksek güvenilirlik düzeyindedir.

Yapılan çalışmada anket sonuçları aşağıdaki şekilde özetlenebilir:

Hem tanımlayıcı hem de ekonometrik olan neredeyse tüm göç araştırmaları, kişilerin öncelikle ekonomik nedenlerden dolayı göç ettiklerini öne sürmektedir. Bu araştırma, genç Türklerin 
incelemesinde de tetikleyici unsurın aynı olduğunu doğrulamıştır. Anket yöntemi kullanılarak elde ettiğimiz veriler, genç Türklerin göç kararının ülkedeki devam eden ekonomik krizden etkilendiğini, diğer bir ifade ile, ekonomik faaliyet ve istihdam olanakları gibi unsurların Türkiye'de gençlerin göç eğilimini etkileyen temel etkenler olduğunu desteklemektedir.

Göç gönderen ve alan ülkelerdeki işgücü piyasası durumu, göç kararlarının arkasındaki en önemli ekonomik faktörlerden biridir. İşgücü piyasasının eğilimlerinden biri olan işsizlik oranıdır (Oğuz, 2011: 706). Türkiye İstatistik Kurumu (TÜIKK)'nun açıkladığı rakamlara göre göre, işsizlik oranı 2009 'da \% 11.0'dan 2019 'da işsizlik oranı Ocak ayından bu yana devam eden yükseliş trendini sürdürerek yüzde 14.7'ye çıkmıştır. Türkiye genelinde 15 ve daha yukarı yaştakilerde işsiz sayısı 2019 yılı Ocak döneminde geçen yılın aynı dönemine göre 1 milyon 259 bin kişi artarak 4 milyon 668 bin kişi olmuştur. Genç nüfusta (15-24 yaş) işsizlik oranı 6,8 puanlık artış ile \%26,7 olurken, 15-64 yaş grubunda bu oran 3,9 puanlık artış ile \%15,0 olarak gerçekleşmiştir (TÜİK, 2019). Bu rakamlar Türkiye'deki gençler açısından oldukça endişe verici düzeydedir. Uzun süre işssizlik, sisteminin verimliliğinin zayıflığı, vb. farklı faktörler gençleri olumsuz ve paradoksal konumlara tabi kılar. Bu faktörler şu sekilde sıralanabilir:

- İşgücü piyasasının bölümlere ayrılması: gençlerin sözleşmeye bağlı zamansallıkları, aleyhlerinde ters çevrilerek, ekonomik yavaşlama aşamalarıyla ilgili aralıklı işsizliğe maruz kalmaları daha sık görülmektedir (Recio, 1999). İstihdama/mesleğe yerleştirilmeleri, istikrarlı bir mesleğin gerçekleştirilmesiyle ve kalıcı bir kariyer geliştirmek için haklar, güvenlik ve imkanlar açısından getirdiği her şeyle direkt olarak örtüşmemektedir.

- Resmi nitelikler ve istihdama/mesleğe yerleştirilmeleri arasındaki karşılıklı etkinin olmaması: sınırlı kaliteli iş arzı, insan sermayesinin kendisinin değer düşüklüğüne uğraması ve kişisel ve profesyonel isteklerin azaltılmasıyla birlikte profesyonel tanıtım ve sosyal hareketlilik için çok az firsat sunar.

- Özerkliklerini ve bağımsızlıklarını pekiştirmek için temel bir araç olarak çalışmanın vurgulanması: sosyal tanıma ve maddi refahı ilgilendiren, çalışma programlarının zayıflatılması, maaş kaynaklarının kıt olması ve kişinin geleceğini yetişkin olarak planlamanın zorluğuyla tezat oluşturmasıdır (Injuve, 2012 : 124).

Çeşitli zorluklarla yetiştirilen bu işgücü kendi vasıflarına ve isteklerine uygun işler bulmadığında yüksek nitelikli işücüne olan talep çerçevesinde başka ülkelerde çalışma imkânlarını değerlendirmekte ve beyin göçüne yönelebilmektedir (Toksöz, 2006: 236-237).

$\mathrm{Bu}$ araştırmanın sonuçları, ekonomik koşullara dayalı göç eyleminde en etkili faktörlerin yeterli kariyer olanaklarının olmayışı, yüksek işsizlik oranı olduğunu ve gençlerin beklentilerinin karşılanmadığını ortaya koymuştur. Bu, Türkiye'deki mevcut durumun, artan vasıflı kariyer talebine ayak uydurması için ülkeyi sınırladığını göstermektedir. Türkiye'deki ekonomik krizi nedeniyle, ülke birçok reformdan da etkilenmiştir. Özellikle geçtiğimiz yıl ve bu yıl boyunca; Türkiye'de, maaşlarda ve ücretlerde şiddetli bir düşüş, sosyal refahta düşüşler, vergilendirmede keskin artışlar ve diğer birçok değişiklik yaşamıştır. Tüm bu sert kesintiler ve önlemler şimdiye kadar en çok etkilenen kısmın genç bireylerin olmasını tetiklemiştir. Bu nedenle, genç ve yetenekli Türk bireylerin, özellikle istihdam nedeniyle yurtdışında yeni bir yaşam arayışı içinde olduklarını söylemek 
mümkündür. Türkiye'de ekonomik krize paralel geleceğe ilişkin umutsuzluklar, gençlerin göç planlarında dikkate değer bir istek artışını tetiklemektedir.

Birincil ekonomik güdülere ek olarak, genç Türkler siyasi koşullara dayanan faktörler nedeniyle de göç etmektedirler. Türkiye'de, ülkedeki gelecekle ilgili karamsar görüşleri ortadan kaldıracak ve genç Türklerin görüşlerini temsil eden hiçbir siyasi parti yoktur. Bu özel ekonomik ve politik faktörler, genç Türklerin Türkiye'den göç etmesi için ana itici faktörlerdir. Öte yandan, bu araştırma göç etme kararında bazı çekme faktörlerinin de bulunduğunu ortaya çıkarmıştır. Genç göçmenlerin hedefinde öncelikle AB ülkeleri bulunmaktadır. Anket sonuçlarına göre, bu oran \%76,9 olarak saptanmıştır. Anket genelinde, katılımcıların AB konusunda olumlu bir imaj/bakış açısına sahip oldukları ve Türkiye'nin $A B$ üyesi olmamasınının kendilerine yansıyan olumsuz bir tarafı olup olmadığına ilişkin görüşleri sorulduğunda ise, bu oranın \%65,9 gibi yüksek çıkmış olması dikkate alınması gereken bir husustur.

Bu sonuca dayanarak, bu çalışmada beyin göçü olgusunun mevcut durumun gözle görülür bir sonucu olduğu sonucuna varabilir. Önceki yıllarda, yurtdışında okumak, Türkiye'ye geri dönüldüğünde daha iyi bir iş bulma yönünde bir adım olarak görülüyordu. Ancak, bugünlerde farklı bir durum ortaya çıkmaktadır. Çünkü, önceki göç dönemleri ile şu anda Türkiye'nin karşılaştığı ülkeler arasındaki fark, ayrılan ya da ayrılmayı düşünenlerin yalnızca vasıfsız işçi değil, aynı zamanda yüksek vasıflı bireyler olduklarıdır.

Geçmişten farklı olarak, bu genç beyinlerin, gidilecek ülkelerde kalma isteğindedirler ve daha iyi bir iş bulmak için geri dönme eğiliminde değillerdir. Beşeri sermaye, kalkınmadaki en önemli faktördür. Ekonomik açıdan bakıldığında, bu, "beyin tahliyesi sermaye yatırımı kaybını temsil ettiği için" ülke için faydalı olmayacaktır. Eğer bir ülke bu değeri kaybederse, bu ciddi bir problemdir (Anderson, 2015). Başka bir deyişle, Türkiye'nin yakın gelecekte yetersiz bir işgücüne yol açabilecek yetenekli insanları ciddi oranda kaybedebilir.

Her ne kadar bu araştırmada elde edilen sonuçlar diğer araştırmaların sonuçları ile tutarlı olsa da, mevcut çalışma bazı sınırlamalar getirebilir. Bu çalışma için halen Türkiye'de bulunan gençlerden elde edilen sonuçları dahil etmek zenginleştirici olacaktır. Ayrıca, sonuçların genelleştirilip değerlendirilemeyeceğini ve diğer anketlerde sunulan kanıtlarla uyuşup uyuşmadığını görmek için bu verileri, burada sunulan bulgular ile karşılaştırmak da ilginç olacaktır. Bu çalışmanın sonuçlarını ölçeklendirmek için ikinci bir kısıtlama ise, ankete katılan kişi sayısıdır. Bu araştırma sadece 122 katılımcı ile yapılabilmiştir. Bu kapsamda ortaya çıkan bu bulguları daha da genelleştirmek için temsili daha geniş bir örneğe sahip olmanın aydınlatıcı olacağı düşünülmektedir.

Son olarak, araştırmaya göre, demografik-sosyo-kültürel koşullara dayanan faktörler; aile, akrabalar ve arkadaş bağlantılarıdır. Ayrıca, hedef ülkenin ekonomik iklimi iyi olduğu sürece nereye göç edebileceği çok önemli bir etken olarak görünmemektedir.

\section{BEYINN GÖÇÜNÜ ÖNLEMEYE YÖNELIKK POLİTIKA ÖNERILERI}

Kuşkusuz, en etkili yöntem itici-çekici faktörlerin etkisini azaltmak ve göçün geçici nitelikte olması için çaba harcamak olacaktır. Göç geçici nitelikte olup da, dışarıda eğitim alan veya bir süre çalışan insanların 
geri dönmesi yabancı araştırma kurumları ile bağ kurulmasına, bilgi akışına ve işbirliğine imkân sağlar. Ortak iktisadi girişimlerin kurulmasını ve yabancı sermaye girişini kolaylaştırır. Güncel çalışmalarda, beşeri sermaye kazanımının ayrıca, eşitlik ve verim ile yakından ilişkili bir alan olduğunu kuvvetle göstermektedir. Bu durum, eğitim yoluyla gelirin seviyesini ve dağılımını etkileyen aktif yeniden dağıtım politikaları olarak adlandırılan politikaları kapsamının önemine işaret etmektedir (Anderson, 2015: 18).

Beyin göçünün kaynak/köken ülkeler açısından olumsuz etkilerini hafifletmek için çeşitli politikalar önerilmektedir. Bu önerileri kısaca şu şekilde sıralamak mümkündür:

Beşeri sermayenin büyüme üzerindeki rolü iyi belirlenmiştir. Oldukça geniş bir literatür, eğitimin verimlilik artışları için önemini ortaya koymuştur. Güncel çalışmalar hem niceliksel hem de niteliksel eğitim önlemlerini içermektedir ve eğitimin verimlilik artışında öneminin büyük olduğu tespit edilmiştir (Anderson, 2015: 18).

1. Eğitim politikaları ile göçü engelleme: Ülkenin ihtiyaçlarına uygun olmayan alanlarda eğitimi geliştirmek beyin göçünü teşvik etmektedir. İhtiyaçlar doğrultusunda nitelikli uzmanlar yetiştirilmeli ve bu kişilerin istihdamı temin edilmelidir.

2. Ekonomik ve sosyal gelişme ile nitelikli işgücünü elde tutma: İnsanların ülkelerinde kalmalarını sağlayıcı ortamlar ve koşullar yaratmak, itici faktörleri çekici hale getirmek gerekmektedir.

3. Dönüş ve dolaşım programlarının desteklenmesi: Dışarıda uzun yıllar kalan ve deneyim sahibi olan uzmanların çalışabilecekleri ve yaşayabilecekleri elverişli koşulların yaratılmasıyla kendi ülkelerine çekilmeleri beyin göçünün olumsuz etkilerinin azaltılmasında büyük önem taşımaktadır. Bu geri dönüşler sürekli olabileceği gibi belli projelerde çalışmak için kısa süreli de olabilir. Bu konuda Kore ve Tayvan başka örnekler sunmaktadır. Kurulan komisyonlar aracılığıyla dönenlerin istihdamına yardımcı olunmakta, mevcut bilim ve teknoloji enstitülerinin düzeyi yükseltilerek dışarıdakileri çekecek cazibeye sahip olmasına çalışılmaktadır.

4. Uzman ağları oluşturma: Bir ülkenin diasporada yaşayan uzmanlarının kendi aralarında oluşturacakları ağlar ile bilgi ve deneyimlerini köken ülkeye aktarmaları durumunda sağlanacak kazanımlar çok önemli olabilmektedir. Bu uzman ağları bilgi ve teknoloji transferinin yanısıra yeni iş bağlantılarının kurulmasında önem taşımaktadır. Bu noktada internet büyük kolaylık sunmaktadır.

Türkiye açısından, beyin göçünü azaltmak için öncelikle kişileri göçe teşvik eden ekonomik ve mesleki kaygıların azaltılması önem taşımaktadır. Bu bağlamda üniversitelere daha fazla kaynak ayrılması, öğretim elemanlarının ücretlerinin artırılması, üniversitelerin eğitim ve araştırma kalitelerinin yükseltilmesi, yurt dişındaki üniversitelerle rekabet edebilir hale getirilmesi ve Türkiye'de öğrenim gören yabancı öğrencilerin bir potansiyel olarak değerlendirilmesi önerilmektedir. Yurt dışında bulunanlarla iletişim ağlarının kurulması ve onların bulundukları yerden ne türlü katkılarının olabileceğinin açığa çıkarılması diğer öneriler olarak sıralanabilir (Toksöz, 2006: 238-240).

\section{SONUÇ}

Bu çalışmada iki yönlü bir amaç takip edilmiştir. Bir yandan, Türkiye'de gençlerin göç eğilimini etkileyen unsurlar, diğer yandan, beyin göçünü önlemeye yönelik politika önerileri incelenmiştir. 
Türkiye'de gençliğin göç projesini, Türkiye'deki iten faktörler ve uluslararası senaryodaki çekiciliği (çekme) dikkate alarak gençlerin gerçekleştirdikleri ussal bir maliyet-fayda yaklaşımının sonucu olduğunu söylemek mümkündür. Göç projesi genellikle yüksek öğrenimin başarılı bir şekilde tamamlanmasında başarılı olmaktadır. Üniversite mezunları, aldıkları eğitime ve elde ettikleri eğitim düzeyine dayanarak göç ederek ve rekabet ederek kariyerlerinin bir sonraki aşamasına geçmek istemektedirler. Göç, daha fazla eğitim ve öğretim döngüsü (özellikle yüksek lisans derecesi) aracılığıyla kendi mesleki profilini güçlendirmek ve özelleştirmek için bir fırsat olabilmektedir. Bu stratejinin amacı, bireyin istihdam edilebilirliğini arttırmak, yani işgücü piyasasında rekabetçi değer kazanmak ve daha fazla istihdam olanakları elde etmektir. Aynı şekilde, bu amaç eğitim sistemi ile işgücü piyasası arasında tutarlı bir geçişi de beraberinde getirmektedir, çünkü bunlar çalışılan ve kalite çalışmalarıyla uyumlu bir iş arayışı göstergesidir.

Genç göçmenler yurtdışında istedikleri iş öncelikleri, iş gücüne yerleştirme ve profesyonel terfi için somut olasılıklardan söz etmektedirler. Neredeyse ankete tüm katılanlar yaşamı boyunca farklı yerlerde yaşamanın zenginleştirici bir seçenek olduğunu düşünmektedirler.

Gelişmiş ülkelerin yüksek nitelikli işgücü açıklarını, gelişmekte olan ülkelerden beyin göçüyle telafi etme stratejileri elbette Türkiye için de etkilerini göstermektedir. Bundan sonra ABD'ye ek olarak AB'ye yönelik olarak beyin göçünün artması muhtemeldir. Türkiye'de düşük nitelikli işgücünün göçüne işsizliği hafifletici bir faktör olarak hükûmetin beyin göçü konusunda geliştirilmiş politikaları henüz bulunmamaktadır. Özellikle beyin göçü çerçevesinde yetişmiş işgücünün geri dönmesi için bu bireylerin göçünü tetikleyen mesleki ve ona paralel ekonomik endişelerin giderilmesi, Ar-Ge faaliyetlerine daha fazla kaynak ayrılması bilim insanlarının gidişlerinin geçici süreli olmasına hizmet edecektir (Toksöz, 2006: 251-252). Bu bağlamda, Tübitak'ın Uluslararası Lider Araştırmacı Programı son dönemde ortaya çıan bir güzel örnektir. ${ }^{3} \mathrm{Bu}$ programların yaygınlaştırılması önem arz etmektedir. Sürekli ülke dışında ikamet edenler açısından ülkedeki gelişmelerden haberdar olabilecekleri ve ayrıca ülkemize katkı sağlayabilecekleri uzman şebekelerin kurulması gereklidir.

\section{KAYNAKLAR}

Anderson, M.T. (2015). Human Capital, Inequality and Growth. European Commission, Discussion Paper 7, September 2015. [Online] https://ec.europa.eu/info/sites/info/files/dp007_en.pdf [Erişim Tarihi : 06.04.2019].

Arango, J. (2000). Enfoques Conceptuales y Teóricos Para Explicar La Migración, Revista Internacional de Ciencias Sociales, n.165.

Bauer, T. and Klaus F. Z. (1999). Assessment of Possible Migration Pressure and Its Labor Market Impact Following EU Enlargement to Central and Eastern Europe. A study for the Department of Education and Employment, UK. IZA Research Report, No.3, July.

Bonin, H. vd. (2008). Geographic Mobility in the European Union: Optimising Its Economic and Social Benefits. IZA Research Report, No. 19. July.

\footnotetext{
${ }^{3}$ Programla ilgili detaylı bilgi için bkz. https://www.tubitak.gov.tr/sites/default/files/2204/2232_turkish.pdf
} 
Castles, S. and Mark J. M. (2009). The Age of Migration. International Population Movements in the Modern World, 4th., Edition, London: Palgrave Macmillan.

Castles, S., H de H., Mark, J.M. (2014). The Age of Migration: International Population Movement in the Modern World, Newyork: The Guilford Press.

Coşkun, R., Altunışık ve R., Yıldırım, E. (2017). Sosyal Bilimlerde Araştırma Yöntemleri: SPSS Uygulamalı, Güncellenmiş 9. Bs., Sakarya: Sakarya Yayıncılık.

de Haas, H. (2008). Migration and Development. A Theoretical Perspective. International Migration Institute Working Paper, No.9. University of Oxford.

de Haas, Hein. (2009a). Migration and Human Development. International Migration Institute Working Paper, No. 14. University of Oxford.

de Haas, H. (2009b). Migration Systems Formation and Decline. A Theoretical Inquiry into the Selfperpetuating and Self-undermining Dynamics of Migration Processes. International Migration Institute Working Paper, No. 19. University of Oxford.

Dustmann, C. and Albrecht, G. (2005). Immigration, Jobs and Wages: Theory, Evidence and Opinion. Centre for Research and Analysis of Migration, CEPR, London.

Dustmann, C., Maria, C., Michael, F., vd. (2003). The Impact of EU Enlargement on Migration Flows, the Immigration and Nationality Directorate of the UK Home Office. Home Office Online Report 25/03.

European Commission. (2000). Push and Pull Factors of International Migration, a Comparative Report, Office for Official Publications of the European Communities, Luxembourg. [Online] https://publications.europa.eu/en/publication-detail/-/publication/90913700-dbbb-40b8-8f85bec0a6e29e83 [Erişim Tarihi : 10.03.2019].

Faist, T. (2000). The Volumes and Dynamics of International Migration and Transnational Social Spaces. Oxford: Oxford University Press.

Geddes, A. and Scholten, P. (2016). The Politics of Immigration in Europe. 2nd. Edition, London: Sage Publications,

Harris, J. and M.P Todaro. (1970). Migration, Unemployment and Development: A two-sector Analysis. American Economic Review, 60: 126-142.

Hicks, J.R. (1932). The Theory of Wages. London: Macmillan.

Injuve, Instituto de la Juventud de España. (2012). [Online] http://www.injuve.es/sites/default/files/Emigracion\%20jovenes_0.pdf [Erişim Tarihi : 10.03.2019].

Kurekova, L. (2011). Teories of migration: Conceptual Review and Emprical Testing in the Context of the EU East-West Flows, (Çev. Ebru Kaya), Akademik Sosyal Araştırmalar Dergisi, Yı1. 6, Sayı.80, Ekim 2018, ss. 697-727. 
Lee, S.E. (1966). A Theory of Migration, Demography, 3/1:47-57.

Lewis, W A. (1954). Economic Development with Unlimited Supplies of Labor, The Manchester School of Economic and Social Studies, 22: 139-191.

Martiskova, M. (2013). What Are the Main Reasons for Young Greeks to Emigrate? University of Twente School of Management and Governance, Enshede, The Netherlands, Master Thesis European Studies.

Massey, Douglas S. (1999). Why Does Immigration Occur? A Theoretical Synthesis. In: Charles Hirschman ve ark. (Eds.), The Handbook of International Migration. The Russell Sage Foundation.

Massey, Douglass S., Arango, J., Hugo, G., Kouaci, vd. (1993). Theories of International Migration: a Review and Appraisal, Population and Development Review, 19 (3): 431-466.

Massey, Douglass S., Arango, J., Hugo, G., Kouaouci, vd. (1998). Worlds in Motion. Understanding International Migration at the end of the Millennium, Oxford: Clarendon Press.

Oğuz, G. (2011). The Impact of Turkish Labour Migration on the Human Resources in the European Union, Procedia Social and Behavioral Sciences, 24, pp. 696-715.

Özcüre, G. (2016). Avrupa Birliği - Türkiye Müzakere Sürecinde Sosyal Politika ve İstihdam, İstanbul: Derin Yayınları.

Özkul, D. (2016). Ulus-Ötesi Göç: Uluslararası Göç Yazınında Yeni Bir Paradigma. Küreselleşme Çağında Göç: Kavramlar, Tartışmalar, (Eds., S. Gülfer Ihlamur Öner, N. Aslı Şirin Öner), 3bs., İstanbul: İletişim Yayınları.

Salomoni, F. (2016). Göç ve Vatandaşlık ve Kimlik Anlayışlarında Yaşanan Değişim. Küreselleşme Çağında Göç: Kavramlar, Tartışmalar, (eds.,S.Gülfer Ihlamur Öner, N.Aslı Şirin Öner), 3bs., İstanbul, İletişim Yayınları.

Sampson, A. (1969). Avrupa Nereye Gidiyor?, (Çev.Nuran Ülken), İstanbul: Sander Yayınları.

Sert, D. (2014): Küresel hareketlilik ve Göç, Küresel Siyasete Giriş: Uluslararası İlişkilerde Kavramlar, Teoriler, Süreçler, (Ed., Evren Balta), İstanbul: İletişim Yayınları.

Sjaadstad, L. (1962). The Costs and Returns of Human Migration, Journal of Political Economy 70: 8093.

Tassinopoulos, A. and Werner, H. (1998). La Movilidad y la Migración de la Fuerza de Trabajo en la Unión Europea, sus Implicaciones Específicas para los Jóvenes, Brussels: Cedefop.

Todaro, Michael P. And Steven S. (2006). Economic Development. Boston: Addison Wesley.

Recio, A. (1999). La Segmentación del Mercado Laboral en España. F. Miguélez y Carlos Prieto (dir. y coord.) Las relaciones de Empleo en España, Siglo XXI, Madrid.

Toksöz, G. (2006). Uluslararası Emek Göçü. 1.Bs., İstanbul: İstanbul Bilgi Üniversitesi Yayınları 129, Göç Çalışmaları. 
Türkiye İstatistik Kurumu (2019). İşgücü İstatistikleri Ocak 2019. [Online] http://www.tuik.gov.tr/PreHaberBultenleri.do?id=30682 [Erişim Tarihi: 15.04.2019].

Vertovec, S. (2002). Transnational networks and skilled labor Migration. Paper given at the conference: Ladenburger Diskurs Migration. Gottlieb Daimler- und Karl BenzStiftung, Ladenburg, 14-15 February.

Wächter, B. (2006). Brain Drain: What We Know and What We Do Not Know. 15 Rue D'Egmont, B 1000,Brussels, Belgium, [Online] https://pdfs.semanticscholar.org/7c83/8682e9aa2bed605dfce5a7673eaf81a1d6bc.pdf [Erişim Tarihi : 10.03.2019].

\section{EKLER}

\section{EK 1:}

\section{ANKETE KATILANLARIN GENEL VERİLERİ}

\begin{tabular}{|l|c|}
\hline Yaş Dağılımı & $\%$ \\
\hline $18-20$ arası & 20,2 \\
\hline $21-25$ arası & 63,6 \\
\hline $26-30$ arası & 16,2 \\
\hline Toplam & 100,0 \\
\hline Cinsiyet & \\
\hline Erkek & 42,8 \\
\hline Kadın & 57,2 \\
\hline Toplam & 100,0 \\
\hline Akademik Seviye & \\
\hline Ögrenci & 39,3 \\
\hline Lise Mezunu & 4,0 \\
\hline Meslek Lisesi Mezunu & 1,2 \\
\hline Üniversite Mezunu & 37,6 \\
\hline Yüksek Lisans ve Dengi Mezunu & 17,3 \\
\hline Toplam & 100 \\
\hline Medeni Hali & \\
\hline Bekar & 74,6 \\
\hline Evli & 23,1 \\
\hline Toplam & 100,0 \\
\hline Çocuğunuz var mı? & \\
\hline Hayır & 85,5 \\
\hline Evet & 14,5 \\
\hline Toplam & 100,0 \\
\hline Yabancı Dil Seviyesi/Ingilizce & $30 \mathrm{kişi}$ \\
\hline Bilmiyorum & \\
\hline Düşük & \\
\hline & \\
\hline
\end{tabular}




\begin{tabular}{|c|c|}
\hline Orta & 85 kişi \\
\hline Yüksek & 52 kişi \\
\hline Toplam & 100,0 \\
\hline \multicolumn{2}{|l|}{ Yabancı Dil Seviyesi/Almanca } \\
\hline Bilmiyorum & 113 kiş \\
\hline Düşük & 54 kişi \\
\hline Orta & 3 kişi \\
\hline Yüksek & 2 kişi \\
\hline Toplam & 100,0 \\
\hline İki Yabancı Dil Bilen & 3 kişi \\
\hline \multicolumn{2}{|l|}{ Ekonomik Faaliyet Sektörü } \\
\hline Hizmet & 52,7 \\
\hline Sanayi & 6,6 \\
\hline Diğer & 40,7 \\
\hline Toplam & 100,0 \\
\hline \multicolumn{2}{|l|}{ Sahip Olunan En Nitelikli Meslek } \\
\hline Hekim & 32,9 \\
\hline Yönetici & 17,3 \\
\hline Profesyonel muhasebe, idari büro çalışanı & 8,1 \\
\hline Mühendis & 9,2 \\
\hline Diğer & 27,7 \\
\hline Toplam & 100,0 \\
\hline \multicolumn{2}{|c|}{ Aylık Gelir TL (tüm kaynakları göz önüne alarak) } \\
\hline Asgari ücretten az & 37,6 \\
\hline $2.000-3.000$ & 20,2 \\
\hline $3.000-5.000$ & 12,1 \\
\hline $5.0000-10.000$ & 21,4 \\
\hline 10.000 ve üzeri & 8,7 \\
\hline Toplam & 100,0 \\
\hline \multicolumn{2}{|c|}{ Ülkenin Ekonomik Durumuna İlişkin Değerlendirme } \\
\hline Çok iyi & 1,7 \\
\hline İyi & 8,7 \\
\hline Normal & 2,9 \\
\hline Kötü & 57,8 \\
\hline Çok kötü & 28,9 \\
\hline Toplam & 100,0 \\
\hline \multicolumn{2}{|c|}{ Bir Yıl öncesine Göre Ülkenin Ekonomik Durumu } \\
\hline Daha iyi & 10,4 \\
\hline Daha kötü & 79,2 \\
\hline Aynı & 10,4 \\
\hline Toplam & 100,0 \\
\hline \multicolumn{2}{|l|}{ Gelecek Yılın Ekonomik Durum Beklentisi } \\
\hline Daha iyi & 8,1 \\
\hline
\end{tabular}




\begin{tabular}{|c|c|}
\hline Daha kötü & 75,1 \\
\hline Aynı & 16,8 \\
\hline Toplam & 100,0 \\
\hline \multicolumn{2}{|l|}{ Başka Ülkede Çalışmayı Düşünenler } \\
\hline Evet & 67,4 \\
\hline Hayır & 32,6 \\
\hline Toplam & 100,0 \\
\hline \multicolumn{2}{|l|}{ Yurt Dışında Yaşamaya Dair Beklentiler } \\
\hline İş beklentileri & 24,9 \\
\hline Eğitim beklentileri & 12,1 \\
\hline Mesleki deneyim beklentileri & 11,0 \\
\hline Kişisel deneyim beklentileri & 33,5 \\
\hline Diğer & 18,5 \\
\hline Toplam & 100,0 \\
\hline \multicolumn{2}{|c|}{ Göç Etmeye Karar Verseniz Aşağıda ki Seçeneklerden Hangisini Tercih Eder siniz? } \\
\hline Avrupa Birliği Ülkeleri & 76,9 \\
\hline ABD. & 16,2 \\
\hline Okyanusya & 6,4 \\
\hline Toplam & 99,5 \\
\hline \multicolumn{2}{|c|}{ Göç Ettikten Sonra Türkiye'ye Yeniden Dönmeyi Planlıyor musunuz? } \\
\hline Evet & 78,2 \\
\hline Hayır & 21,8 \\
\hline Toplam & 100,0 \\
\hline \multicolumn{2}{|c|}{ Türkiye'ye Geri Dönmek İstememenizin Önemli İki Nedeni } \\
\hline İşsizlik/ Ekonomik durum & 11 \\
\hline Gelecek için imkanların iyi olmaması & 49,7 \\
\hline Yurtdışında yaşamayı severim/yeni kültür edinmek & 10,3 \\
\hline Sosyal ağ bağlantısının/çevresinin az olması & 0,6 \\
\hline Bir süre sonra her halükarda geri döneceğim & 28,4 \\
\hline Toplam & 100,0 \\
\hline \multicolumn{2}{|l|}{ Avrupa Birliğine (AB) İlişkin Bakış Açısı } \\
\hline Çok olumlu & 10,4 \\
\hline Olumlu & 37,6 \\
\hline Nötr & 39,3 \\
\hline Olumsuz & 9,8 \\
\hline Çok olumsuz & 2,9 \\
\hline Toplam & 100,0 \\
\hline \multicolumn{2}{|c|}{$\begin{array}{l}\text { Türkiye'nin AB Üyesi Olmamasınının Size Yansıyan Olumsuz Tarafı Olduğunu } \\
\text { Düşünüyor musunuz? }\end{array}$} \\
\hline Evet & 65,9 \\
\hline Hayır & 34,1 \\
\hline Toplam & 100,0 \\
\hline
\end{tabular}

